\title{
The Effect of IPOs on German Family-Owned Firms: Governance Changes, Ownership Structure, and Performance
}

\author{
Olaf Ehrhardt ${ }^{*}$ \\ Institute of Banking, Stock Exchanges, and Insurance \\ Humboldt University Berlin, \\ Spandauer Str. 1 \\ D-10178 Berlin \\ E-Mail: ehrhardt@wiwi.hu-berlin.de. \\ Eric Nowak \\ Goethe-University Frankfurt \\ Department of Finance \\ Mertonstr. 17-25 \\ D-60325 Frankfurt am Main / Germany \\ Phone: +49-171-6219913 \\ Email: enowak@wiwi.uni-frankfurt.de
}

Keywords: Family Enterprises, IPOs, Ownership Structure, Corporate Governance

JEL classification: $G 14, G 32, G 15$

\footnotetext{
* Dr. Olaf Ehrhardt is post doctoral researcher at the Institute of Banking, Stock Exchanges, and Insurance at the Humboldt University Berlin and project manager at Aios Corporate Finance GmbH. He studied Business Administration at the Humboldt University and holds an doctoral degree from the same university. His current interests are corporate finance (initial public offerings, corporate governance, valuation of firms) and empirical research of capital markets. Dr. Eric Nowak is Visiting Professor of Banking and Finance at the University of Hohenheim and Privatdozent at the Goethe-University Frankfurt, Germany. His current research interests are Empirical Corporate Finance, Corporate Governance, Venture Capital, and Law \& Finance.

This paper is part of a research project presented at the CEPR Research Conference in Courmayeur, Fall 2000 WAFA Conference in Washington, D.C., the European Economic Association Conference in Bozen, the ABN AMRO International Conference on IPOs in Amsterdam, the SIRIF Conference on Corporate Governance, Edinburgh, the Financial Center Seminar at the Tinbergen Institute, Rotterdam, and the G-Forum on Entrepreneurship Research at the Wirtschaftsuniversität, Vienna. We are grateful to Bruno Bias, Salvatore Cantale, Marco da Rin, Andreas Dische, Julian Franks, Alan Gregory, Dirk Jenter, Gunther Löffler, Richard Stehle, Don Strickland, Christian Wulff, and participants at the seminars and conferences mentioned above for helpful comments. We thank Stefan Schröter for providing the data on ownership structure, and Craig R. Bain for language proofing.
} 


\section{Introduction}

Although initial public offerings (IPOs) have recently attracted public and academic attention, the special case of firms founded by families or single entrepreneurs has not been investigated in depth. Given the lack of empirical research on family-controlled businesses (McConaughy, Matthews and Fialko 2001), this study is an attempt to remedy this deficiency. For family-owned firms, a change in ownership structure by going public is a significant change in the governance of the corporation, because for the first time outside shareholders come into play. This pattern is typically to be observed for IPOs of family-owned firms in Germany. ${ }^{1}$

Our paper merges two strands of research: on the one hand, the entrepreneurial literature on family-controlled businesses, on the other hand, the vastly increasing research on corporate governance and initial public offerings (IPOs). After reviewing some of the related literature, we present empirical evidence about (i) the change in corporate governance (as proxied by a change in the ownership structure) following IPOs, and (ii) its impact on the long-run stock performance of family-owned firms in Germany. We conclude with a summary of the major findings.

\section{Related Literature}

Franks and Mayer (2001) report that family business shareholdings account for one third of total shareholdings in Germany. They argue that family investors, since their wealth is directly tied to that of the family firm, seem to exert strong disciplining of poorly performing management. For the US, Kang (2000) and McConaughy, Matthews and Fialko (2001) find that family controlled firms have greater value and are operated more efficiently than non-founding

\footnotetext{
${ }^{1}$ We classify a firm as founding family owned, if one or more individual members of one or two founding families (together) own a fraction of the equity of at least 50 percent. This is different from the definition of founding family controlled firms used McConnaughy, Matthews and Fialko (2001).
} 
family controlled firms. In a recent article, Bhattacharya and Ravikumar (2001) show that the development of efficient capital markets accelerates the evolution and the sale of family businesses. Thus, the public sale of family-owned firms and their resulting performance is a topic with growing importance.

In Germany there were at least three factors, which prohibited founding families from selling their firms, during our investigation period. One, tax regulation made the sale of privately held equity stakes less attractive. Although the profit on the sale of exchange-traded shares is taxexempt after a holding period of one year, selling stakes in non-quoted companies is taxed at high rates. Two, low competition in the underwriting market and thereby high direct costs of an IPO led to capital-raising firms preferring Hausbank-financed debt financing or private placements. Three, German ideas on family values and the corporate mission of family-owned firms also resulted in many owners rather not taking public their firms (Schürmann and Körfgen 1997).

Goergen and Renneboog (2002) provide a comparative study on the evolution of ownership and control in German and UK IPOs. They found that initial shareholders (including families) lose majority control on average six years after the IPO in Germany. However, in two thirds of their sample of 52 German IPOs, initial shareholders retain absolute majority control, and the probability of retaining control concentration augments when non-voting shares are issued. Goergen (1998) studied ownership retention in German and UK IPOs, the determinants of ownership retention, and its impact on IPO long-term performance. He found that the long-run performance of IPOs is not correlated with ownership retention. Overall, he suggests that the poor long-term performance of IPOs in his sample, compared to the stock market as a whole, cannot be explained by agency conflicts caused by the reduction in ownership by the original shareholders. 
We focus our attention on the strategic decisions of family-owners floating their firms. We restrict our analysis for the following reasons. First, family-owned firms have long been the most typical firms in Germany to undertake a change of ownership by means of an IPO. Second, a family-owned firm comes closest to one in which ownership and control are not separated until the IPO, making it ideal for investigating the performance effect of a change in the corporate governance structure. In the next section, we present the theoretical background for building our testable hypotheses.

\section{Governance Changes in Family Firms through IPOs}

\section{Founding Family Stockholders’ Strategic Decisions}

An equity sale through an IPO has two distinct features. First, by definition it induces a change in the ownership structure of the firm. Second, given the presence of high initial returns, it leads to a transfer of wealth from the incumbent owners to the new shareholders. For a firm with a given investment program, an artificially low IPO price ("underpricing") leads to a proportionate reduction (increase) in incumbent (new) shareholder wealth. The high level of information asymmetry at the IPO induces insiders to sell equity both in the new issue market and in the secondary market. Through the signaling by underpricing and high ownership retention, insiders benefit from inducing information production by outside investors in order to obtain a more precise valuation of their firms in the secondary market (Leland and Pyle 1977; Chemmanur 1993).

In addition to the issuance volume and the price range of the IPO, the choice between the classes of issued shares (ordinary vs. non-voting/ preferred stock) has an impact on the resulting 
ownership structure of the firm. ${ }^{2}$ The detailed specifications of the IPO are contracted upon between the issuing firm, its advisors, and the lead underwriter.

We only investigate German IPOs that are issued by family-owned firms, or are at least governed by a controlling stake of the founding family. The terms of the issuance contract are then driven by the founding family's intention to keep control of the firm even after the IPO, if not a complete sale (exit) is planned in the short- or mid-term. ${ }^{3}$ The models discussed below suggest that the terms and conditions of an IPO are contracted upon by the family owner according to strategic considerations with respect to the future ownership structure of the firm.

These strategic considerations are driven by the incumbent shareholders' desire to maximize their expected long-run returns from their equity holdings and their private benefits from owning the firm. Assuming rational expectations and optimal contracting with respect to the economic consequences of ownership changes, as well as perfect competition between firms and managers, measures of ownership concentration should not be correlated with stock returns. ${ }^{4}$ However, if (one or more of) these assumptions are violated, irrelevance of the ownership structure does no longer hold, resulting in systematic differences in the cost of governing the firm. ${ }^{5}$ Given that these differences exist, they should empirically be verifiable by positive or negative abnormal returns depending on the level of ownership concentration.

\footnotetext{
${ }^{2}$ Also a high dispersion of ownership of the ordinary shares might lead to a high proportion of proxy voted shares by the underwriting banks in the IPO. However, Franks and Mayer (2001) find that proxy voting is of negligible importance in the presence of a large shareholder.

${ }^{3}$ There are several hints in the literature that family owners fear an involuntary transfer in the corporate governance structure of the corporation. This is one of the main reasons given for the observed reluctance to going publics of family-owned firms in Germany. See for example Schürmann and Körfgen (1997).

4 This classic argument is given by Demsetz (1983).

5 Shleifer and Vishny (1997) give an overview on agency-costs and corporate governance. See also Allen and Winton (1995).
} 
Models of Ownership Changes through IPOs

IPO related models of ownership structure changes focus on the role of an initial public offering in maximizing the proceeds that an initial owner obtains when selling equity to the public. Intuitively, the proportion of ownership must depend on the optimal combination of majority control and dispersed ownership that maximizes the founding family's wealth.

In Zingales' (1995) model, the initial owner of a firm, in deciding whether to undertake an IPO and what fraction of ownership to retain, must balance two factors. By selling to disperse shareholders, he maximizes his proceeds from the sale of cash flow rights. However, by direct bargaining with a potential buyer, he maximizes his proceeds from the sale of control rights. The insider's ownership in public companies depends on the optimal combination of the value of cash flow rights and the value of control rights that maximizes the incumbent owner's wealth. Thus, the initial owner maximizes his total proceeds by selling the company in a two-staged process.

Bebchuk (1999) models the decision of a company's initial owner on whether to maintain control when the company goes public. The choice between concentrated and dispersed ownership of corporate shares and votes seems to be determined by the size of private control benefits. When private benefits of control are large, maintaining control of the company enables the initial shareholders to capture a larger fraction of the surplus from value-producing transfers of control. In order to maintain control of the firm, the initial owners can issue non-voting stock, thereby implementing a dual-class shareholder structure. He derives the testable hypothesis that such a separation of cash flow rights and voting rights will tend to be used in conjunction with a controlling shareholder structure but not with a dispersed ownership structure. In that context, many family-owned firms issue non-voting preferred stock, in order to prevent that the founding family may no longer hold the absolute majority of the voting rights. 


\section{Empirical Analysis}

We analyze 105 IPOs of founding family-owned firms floated in the period from January 1970 to December 1990. The average (median) age of a sample family firm is 63.6 (58) company years. Pagano, Panetta and Zingales (1998) investigate a sample of 68 Italian IPOs floated on the Milan stock exchange from 1982 through 1992 and report an average (median) age of 33.4 (26) years. Rydqvist and Högholm (1995) report a European average IPO age of 40 years. Holmén and Högfeldt (2000) analyze a sample of 158 privately controlled Swedish IPOs from 1979 to mid 1997 and find an average age of 33 years. For the US, the respective average age figures lie between five years for venture-backed firms (Gompers 1996) and 18 years (Field and Karpoff 2002). Although European IPOs are generally older than their US counterparts, the family firms in our sample are at a very late stage in their lifecycle, even compared to European standards.

\section{Corporate Governance Changes}

Figure 1 contains the proportion of voting rights of families and other shareholders ten years after the IPO. Several observations can be drawn from the results. At first sight, ten years after the IPO, the founding family shareholders seem to have withdrawn from the company, because the average proportion of voting rights is only 40.4 percent. However, for those 60 percent of firms where the founding family is still involved, the mean proportion of the controlling stake is 63.1 percent. In the 34.3 percent of all cases where a transfer of ownership resulted in a change in the corporate governance of the firm, the new controlling blockholder holds 80.3 percent, on average. Overall, the influence of family stockholders remains high for ten years following the IPO, and the founding family continues to exercise considerable influence on corporate control. 
[Please insert Figure 1 about here]

\section{Evolution of Ownership Structure and the Separation of Cash Flow and Control Rights}

According to Bebchuk (1999), the choice between concentrated and dispersed ownership of corporate shares and votes seems to be determined by the size of private control benefits. When private benefits of control are low, the initial owner chooses a dispersed ownership structure and sells out ordinary shares at the IPO. In countries, such as Germany, in which private benefits of control are supposedly large, the founding family often maintains a lock on control through the separation of cash flow rights and voting rights. The results of his model imply that non-voting shares are issued at the IPO only in cases where the majority of voting rights is retained by the family shareholders.

This is indeed the case, as is evidenced by Table 1 . The mean proportion of voting rights even ten years after the IPO is still 51.8 percent for firms that issue non-voting preference shares. This proportion is significantly different from the mean proportion of voting rights when ordinary shares are issued at the time of the offering ( 31.7 percent), supporting the hypothesis of Bebchuk (1999). In order to keep their private benefits of control in the long run, some family owners have established a dual-class share structure. Those that did not issue non-voting preferred stock have given up the majority of voting rights already five years after the IPO, on average.

[Please insert Table 1 about here] 
Founding Family Control and Long-Run Stock Performance

Jensen and Meckling (1976) show that the larger the firm becomes, the larger are the total agency costs because it is likely that monitoring is more difficult and thus more expensive. They argue that if a firm's manager holds a larger fraction of its common stock, agency problems are brought under control by better aligning the manager's interests with those of the shareholders.

Leland and Pyle (1977) in their model show, that managers of high-quality firms can signal by increasing leverage and holding larger equity stakes. Consequently, firms with high leverage have a larger fraction of inside ownership and are, on average, of better quality. Thus, they suggest a positive linear relation between inside ownership and the market value of the firm. Since within family-owned firms, managerial control is often exerted by family members, this linear relation could be assumed for most of the firms in our sample. However, empirical evidence does not seem to support this linearity hypothesis of concentrated ownership and firm performance in a convincing fashion. ${ }^{6}$

Demsetz (1983) and Demsetz and Lehn (1985) argue that the firm's owners determine the ownership structure in a systematically value-maximizing way. According to them, since the ownership structure is optimally chosen, it cannot have any impact on the value of the firm- and therefore, on its performance. ${ }^{7}$ The results of Goergen (1998) seem to support the hypothesis of no relation between long-run performance and ownership. However it should be noted that the rationale of the initial owners is not to maximize total firm value or total shareholder returns, instead their goal is to maximize the sum of the value of the returns to their holdings of cash flow rights and their private benefits. Investigating long-run stock performance therefore is looking from the perspective of the small (minority) investors.

\footnotetext{
${ }^{6}$ See Böhmer (1993), or Krinsky and Rotenberg (1988), for empirical tests of the Leland-Pyle model.

${ }^{7}$ See Demsetz and Lehn (1985).
} 
In order to detect a possible impact of ownership changes on performance, we examine the relation between voting rights concentration of family stockholders in the first three years following the IPO and the corresponding long-term stock returns. For our analysis, we construct buy-and-hold abnormal returns (BAHRs) based on the difference between the result of buy-andhold investments in IPO stocks and the result of buy-and-hold investments in a size-matched benchmark portfolio.

On average, the long-run underperformance of the IPO firms in our sample is about minus eight percent (Table 2). However, this underperformance can be attributed merely to the underperformance of the non-voting shares issued. The performance of the ordinary shares issued at the IPO is neutral and not significantly negative from zero. The underperformance of the nonvoting shares in our sample is much higher being almost minus 20 percent. Although the difference in means between the two subsamples is not statistically significant at a reasonable level, the economic insight of this pattern is strong. ${ }^{8}$

We further examine the proportions of voting rights of family stockholders three years after market flotation. The firms are allocated to one of four classes, and the mean excess return calculated for each of these classes. The results presented in the lower part of Table 2 show that a high concentration of voting rights (VR $>75$ percent) leads to a significantly negative abnormal return, on average. This observation is especially evident for firms that issue non-voting stock.

The long-term stock return is also negative when family stockholders pull back from the firm (VR $<25$ percent). In these firms, the proportion of voting rights of a single, new large stockholder is significantly higher than in the other firms examined. Positive cross-sectional excess returns are observed for voting right concentrations of between 25 percent and 75 percent.

\footnotetext{
${ }^{8}$ We think that the low significance is simply driven by the small sample size in conjunction with high standard variation. Further testing with larger samples has to validate our results.
} 
According to our results, especially high market valuations of the firm can be achieved when family stockholders reduce their proportion of voting rights to between 25 and 50 percent. These observations - although lacking statistical significance - suggest the possibility of a nonlinear relation between the concentration of voting rights and the returns the cash flow rights of a firm.

[Please insert Table 2 about here]

\section{Conclusion}

Even ten years after the IPO, founding family owners continue to exercise considerable corporate control. Thus, the influence of family shareholders on their firms can be preserved usually, despite the financing of equity capital through public offerings. We do not find support for the hypothesis that founding family shareholders maximize their proceeds from the sale of their shares. Although they always sell cash flow rights, the final complete sale of a corporate stake rarely seems to be the motive for a market flotation. It seems that returns to private benefits are higher accruing to the founding family than to other large shareholders. Also, the poor return development of these firms does suggest a maximization of total returns to the large shareholders while expropriating rents from minority shareholders. The private benefits of control for family shareholders seem to be so large that it never pays them to sell the firm completely.

We find strong evidence for Bebchuk's hypothesis (1999), that the separation of cash flow rights and voting rights will tend to be used in conjunction with a controlling shareholder structure but not with a dispersed ownership structure. In order to keep the private benefits from control, incumbent owners establish dual-class share structures. Finally, we find some evidence for the existence of a nonlinear relation between the concentration of voting rights and the stock performance of a firm. The empirical results posit that new shareholders in family founded firms 
should beware when only non-voting shares are issued. Voting rights concentrations above 75 percent seem to be value-decreasing. 


\section{References}

Allen, Franklin and Andrew Winton (1995). "Corporate Financial Structure, Incentives and Optimal Contracting," in Handbooks in Operations Research and Management Science 9. Eds. R. Jarrow, V. Maksimovic and W. Ziemba. Amsterdam, Holland: Elsevier, 693-720.

Bebchuk, Lucian A. (1999). "A Rent-Protection Theory of Corporate Ownership and Control," John M. Olin Center for Law, Economics, and Business, Working Paper 260, Harvard University.

Bhattacharya, Utpal and B. Ravikumar (2001). "Capital Markets and the Evolution of Family Businesses," Journal of Business 74 (2), 187-219.

Böhmer, Ekkehard (1993). "The Informational Content of Initial Public Offerings: A Critical Analysis of the Ownership-Retention Signalling Model," International Review of Financial Analysis 2 (2), 77-95.

Chemmanur, Thomas J. (1993). "The Pricing of Initial Public Offerings: A Dynamic Model with Information Production, Journal of Finance 48 (1), 285-304.

Demsetz, Harold (1983). "The Structure of Ownership and the Theory of the Firm," Journal of Law and Economics 16 (6), 375-390.

Demsetz, Harold and Kenneth Lehn (1985). "The Structure of Corporate Ownership: Causes and Consequences," Journal of Political Economy 93 (6), 1155-1177.

Field, Laura C. and Jonathan Karpoff (2002). "Takeover Defenses of IPO Firms," Journal of Finance 57 (5), 1857-1889.

Franks, Julian and Colin Mayer (2001). "Ownership, Control and the Performance of German Corporations," Review of Financial Studies 14 (4), 943-977.

Gompers, Paul (1996). "Grandstanding in the Venture Capital Industry," Journal of Financial Economics 42 (1), 133-156.

Goergen, Marc (1998). "Insider Retention and Long-Run Performance in German and UK IPOs," Working Paper, University of Manchester Institute of Science and Technology.

Goergen, Marc and Luc Renneboog (2002). "Prediction of Ownership and Control Concentration in German and UK Initial Public Offerings," in Convergence and Diversity in Corporate Governance Regimes and Capital Markets. Eds. L. Renneboog, J. McCahery, Oxford University Press, 2002.

Holmén, Martin and Peter Högfeldt (2000). “A Law and Finance Analysis of Initial Public Offerings," Working Paper, Stockholm School of Economics.

Jensen, Michael C. and William H. Meckling (1976). "Theory of the firm: Managerial Behavior, Agency Costs, and Ownership Structure," Journal of Financial Economics 3 (4), 305-360.

Kang, David L. (2000). "Family Ownership and Performance in Public Corporations: A Study of the U.S. Fortune 500, 1982-1994,” Harvard Business School Working Paper 00-051.

Krinsky, Itzhak and Wendy Rotenberg (1988). "The Valuation of Initial Public Offerings," Contemporary Accounting Research 5 (2), 501-515. 
Leland, Hayne E. and David Pyle (1977). "Information Asymmetries, Financial Structure and Financial Intermediation," Journal of Finance 32 (2), 737-748.

McConaughy, Daniel L., Charles H. Matthews and Anne S. Fialko (2001). "Founding Family Controlled Firms: Efficiency, Risk, and Value," Journal of Small Business Management 39 (1), 31-49.

Pagano, Marco, Fabio Panetta, and Luigi Zingales (1998). "Why Do Companies Go Public? An Empirical Analysis," Journal of Finance 53 (1), 27-64.

Rydqvist, Kristian, and Kenneth Högholm (1995). "Going Public in the 1980s: Evidence from Sweden,” European Financial Management 1 (3), 287-316.

Schürmann, Walter and Kurt Körfgen (1997). Familienunternehmen auf dem Weg zur Börse, München: Beck.

Shleifer, Andrei and Robert W. Vishny (1997). "A Survey of Corporate Governance," Journal of Finance 52 (2), 737-783.

Zingales, Luigi (1995). "Insider Ownership and the Decision to Going Public," Review of Economic Studies 62 (3), 425-448. 
Table 1

Evolution of Ownership Structure through Time

\begin{tabular}{|c|c|c|c|c|c|c|}
\hline & \multicolumn{6}{|c|}{$\begin{array}{l}\text { Mean Proportion of Voting Rights } \\
\text { Held by Old and New Shareholders (percent) }\end{array}$} \\
\hline & \multicolumn{2}{|c|}{ All IPOs } & \multicolumn{2}{|c|}{$\begin{array}{l}\text { Ordinary Shares } \\
\text { Issued at the Time } \\
\text { of the Offering }\end{array}$} & \multicolumn{2}{|c|}{$\begin{array}{l}\text { Non-Voting Shares } \\
\text { Issued at the Time } \\
\text { of the Offering }\end{array}$} \\
\hline & Mean & Median & Mean & Median & Mean & Median \\
\hline \multicolumn{7}{|l|}{ Pre-IPO } \\
\hline Family Shareholders ${ }^{a}$ & 98.24 & 100.00 & 98.59 & 100.00 & 97.74 & 100.00 \\
\hline Other Old Shareholders ${ }^{b}$ & 1.76 & 0.00 & 1.41 & 0.00 & 2.26 & 0.00 \\
\hline \multicolumn{7}{|l|}{ At the IPO } \\
\hline Family Shareholders ${ }^{a}$ & 77.07 & 75.06 & 62.33 & 66.70 & 97.50 & 100.00 \\
\hline Other Old Shareholders ${ }^{b}$ & 0.89 & 0.00 & 0.72 & 0.00 & 1.31 & 0.00 \\
\hline New Blockholders ${ }^{c}$ & 0.57 & 0.00 & 0.98 & 0.00 & 0.00 & 0.00 \\
\hline Free Float & 21.47 & 23.00 & 35.97 & 33.30 & 1.19 & 0.00 \\
\hline \multicolumn{7}{|l|}{3 Years after the IPO } \\
\hline Family Shareholders ${ }^{\text {a }}$ & 67.93 & 70.00 & 54.18 & 59.00 & 86.98 & 100.00 \\
\hline Other Old Shareholders ${ }^{b}$ & 0.48 & 0.00 & 0.55 & 0.00 & 0.85 & 0.00 \\
\hline New Blockholders ${ }^{c}$ & 7.15 & 0.00 & 9.43 & 0.00 & 3.97 & 0.00 \\
\hline Free Float & 24.44 & 25.00 & 35.84 & 34.70 & 8.20 & 0.00 \\
\hline \multicolumn{7}{|l|}{5 Years after the IPO } \\
\hline Family Shareholders a & 57.85 & 63.00 & 47.00 & 51.00 & 72.90 & 95.10 \\
\hline Other Old Shareholders ${ }^{b}$ & 0.37 & 0.00 & 0.21 & 0.00 & 0.58 & 0.00 \\
\hline New Blockholders ${ }^{c}$ & 16.93 & 0.00 & 17.66 & 0.00 & 15.93 & 0.00 \\
\hline Free Float & 24.85 & 24.97 & 35.13 & 36.00 & 10.59 & 0.00 \\
\hline \multicolumn{7}{|l|}{10 Years after the IPO } \\
\hline Family Shareholders ${ }^{a}$ & 40.36 & 38.90 & 31.73 & 27.00 & 51.81 & 60.00 \\
\hline Other Old Shareholders ${ }^{b}$ & 0.10 & 0.00 & 0.18 & 0.00 & 0.00 & 0.00 \\
\hline New Blockholders ${ }^{c}$ & 33.47 & 10.97 & 33.14 & 14.10 & 33.91 & 5.00 \\
\hline Free Float & 26.07 & 24.45 & 34.95 & 34.00 & 14.28 & 5.00 \\
\hline Number of Observations & 105 & & 61 & & 44 & \\
\hline $\begin{array}{l}\text { Bankruptcies ( } 10 \text { Years after } \\
\text { the IPOs) }\end{array}$ & 5 & & 4 & & 1 & \\
\hline
\end{tabular}

Sources: IPO database at the Institut für Bank-, Börsen- und Versicherungswesen, Humboldt-Universität zu Berlin; Hoppenstedt; Saling-Aktienführer; Commerzbank "Wer gehört zu wem".

${ }^{\text {a }}$ Family shareholders are defined as one or more individual members of the same family jointly holding a fraction of the equity.

${ }^{\mathrm{b}}$ Other old shareholders are institutional shareholders, management, employees, and individual shareholders include pre-IPO managerial ownership, and other privately placed shares.

${ }^{c}$ New blockholders are domestic firms, foreign firms, banks and insurance companies, trust and investment companies and individuals. 
Table 2

Performance and Founding Family Control

\section{Long-Run (36 month) Performance of IPOs and Founding Family Owned Stake}

\begin{tabular}{lcccc} 
& $\begin{array}{c}\text { Mean }(t \text { value }) \\
\text { percent }\end{array}$ & $\begin{array}{c}\text { Median }(z \text { value }) \\
\text { percent }\end{array}$ & $\mathrm{N}$ \\
\hline All IPOs & -8.09 & $(-1.28)$ & $-14.29^{* *}(-2.49)$ & 105
\end{tabular}

Voting Proportion of Founding

Family Stake three Years after IPO

$\begin{array}{rrrrrr}0<\text { Voting Rights } \leq .25 & -25.48 & (-1.51) & -24.92 & (-1.26) & 8 \\ .25<\text { Voting Rights } \leq .50 & 60.83 & (1.61) & 41.19 & (1.18) & 7 \\ .50<\text { Voting Rights } \leq .75 & -2.75 & (-0.25) & -13.24 & (-1.32) & 41 \\ .75<\text { Voting Rights } \leq 1.00 & -19.58^{* * *} & (-2.74) & -32.16^{* * *}(-2.63) & 49\end{array}$

Exit of Family Owners three to ten

Years after Going Public

$\begin{array}{lrrrrr}\text { Exit } & -11.08 & (-1.02) & -15.10^{*} & (-1.91) & 36 \\ \text { No Exit } & -6.54 & (-0.84) & -13.61^{*} & (-1.73) & 69 \\ \text { Mean Difference }(t \text { value; } z \text { value }) & & 0.34 & & 0.43 & \end{array}$

Type of Shares Issued at the IPO

$\begin{array}{lccccc}\text { Ordinary Shares Issued } & 0.21 & (0.02) & -10.98 & (-1.30) & 61 \\ \text { Non-voting Shares Issued } & -19.61^{* *} & (-2.64) & -20.08^{* *} & (-2.50) & 44 \\ \text { Mean Difference }(t \text { value; } z \text { value }) & & 1.56 & & 1.03 & \end{array}$

Dual Class Shareholder Structure

$\begin{array}{lrrrrr}.75 \leq \text { Voting Rights } \leq 1.00 & -21.32^{* *} & (-2.56) & -18.94^{* *} & (-2.48) & 36 \\ \text { Voting Rights }<.75 & 6.09 & (0.37) & 10.65 & (0.31) & 12 \\ \text { Mean Difference }(t \text { value }) & & -1.59 & & -1.41 & \end{array}$

Outliers Analysis

(trimmed mean, 5 percent)

$\begin{array}{lrcr}.75 \leq \text { Voting Rights } \leq 1.00 & -21.45^{* * *} & (-2.86) & 32 \\ \text { Voting Rights }<.75 & 4.91 & (0.38) & 10 \\ \text { Mean Difference }(t \text { value }) & & -1.73^{*} & \end{array}$

$\mathrm{N}=$ No. of observations; ${ }^{* * * * * *}$ indicate statistical significance at the 10,5 , and 1 percent levels, respectively. $\mathrm{H}_{0}$-hypothesis are tested by $t$-test (mean) and Wilcoxon signed-rank test (median), respectively. Two-sample $t$-test and two-sample Wilcoxon rank-sum (Mann-Whitney) test look for differences in means (median) between the two sample partitions. 
Figure 1

Governance Changes Ten Years after the IPO

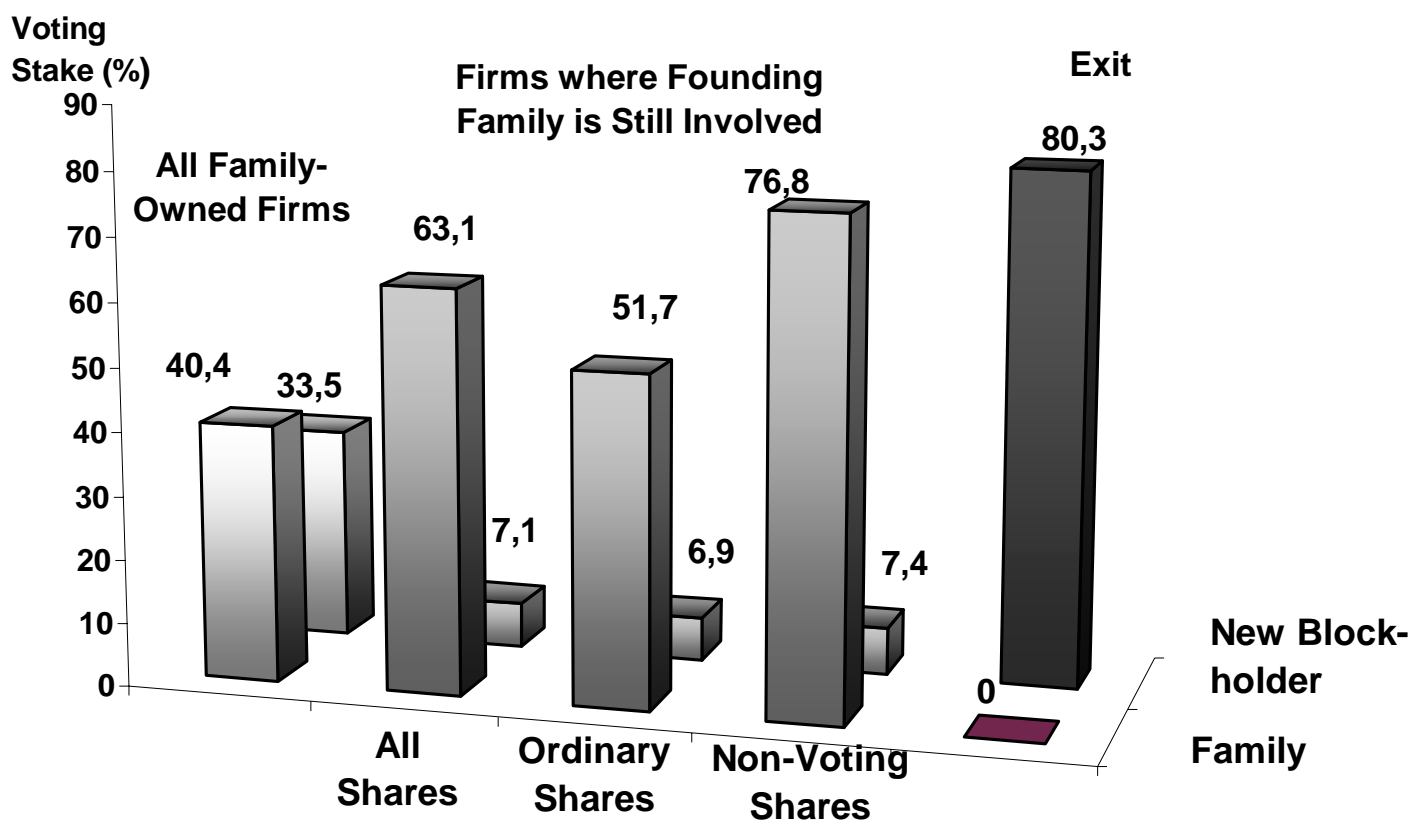

